\title{
Acknowledgments
}

My work on this project was made possible thanks to the help and support of a great many people and institutions. A generous Sexuality Research Dissertation Fellowship from the Social Science Research Council not only allowed me to travel to archives across the United States but also put me in touch with scholars who grappled with issues of identity and coming of age from a variety of disciplinary perspectives. The University of Massachusetts at Amherst provided additional funding, and I spent one of the best years of my life at the Five College Women's Studies Research Center at Mount Holyoke College in the company of some simply amazing female scholars and artists. I also owe a huge debt to the staff at the Smith College and the Mount Holyoke College Archives, the Center for Archival Collections at Bowling Green State University, the Schlesinger Library on the History of Women in America, the Bentley Historical Library at the University of Michigan at Ann Arbor, the Iowa Women's Archives in the University of Iowa Libraries in Iowa City, the Louis Round Wilson Special Collections Library at the University of North Carolina at Chapel Hill, and the American Jewish Archives at Hebrew Union College in Cincinnati, Ohio. I would never have noticed a number of my sources had it not been for the suggestions of a librarian or archivist, and while the staffs were great in all the repositories I visited, I want to thank especially Nanci Young at Smith College and Patricia Albright at Mount Holyoke for all their help. Margaret Whitfield, Sheila Owen Monks, Leilah Jackson Poullada, Elinor Offill, and Marjorie Hibbard Lauer shared with me their diaries and letters from student days, and I can only hope that my analysis confirms their sense that they could trust me with their private papers.

I also want to emphasize the debt I owe to the historians with whom I had the pleasure and honor of working. Norbert Finzsch at the University of Hamburg in Germany first introduced me to the study of women and gender. After I moved to the United States, Joanne Meyerowitz, Kathy Peiss, Kevin Boyle, Laura Lovett, Daniel Horowitz, and Joyce Berkmann made sure that I was on top of the literature. Rachel Devlin and John Spurlock commented on presentations of my work at an early stage of the research and Daniel Horowitz, Laura Lovett, Christine Stansell, Jessica Delgado, Constance Ostrowski, Eileen Abrahams, 
and Anna Biel read drafts of this book and gave helpful feedback on revisions. Thanks as well to the anonymous readers for Rutgers University Press for their insights and suggestions, and to Leslie Mitchner and Katie Keeran at the press, and to Patti Bower, for their patience and support.

Throughout the research for and the writing of this book, many of my relatives, friends, and colleagues have rooted for me. My parents, Inge and Bruno Fähmel, my brother, Sascha, and my grandmother, Hilde Purschke, followed my work from a distance but always with interest. Sadly, neither my father nor my grandmother lived to see the completion of this book. I hope, however, they knew how much I wanted them to be proud of me. When I was getting close to the finish line with this project, my department chair, Carol DeFries, offered good cheers whenever she saw me morph into a headless chicken. Colleague Reneé Adamany always found exactly the right words when she saw my anxiety level spike, and office mate Eric Carlson kindly shared his insights into adolescent psychological development and supplied me with readings. I owe the largest debt to the people who offered me their friendship while I was struggling with the completion of a project that turned out to be a lot more intricate than I thought it would be when I started it as a somewhat conceited graduate student: Elizabeth Ramey, Adam Chill, Jessica Delgado, Liane Jeschull, Bill Bergmann, Barbara Hahn, Nela Trifkovic, Heather Murray, Julia Sandy-Bailey, Sara Connolly, Bill Weye, Ed and Ineke Valerio, Nora Groves, Bob Nakosteen, and Sibylle Warnecke; thank you all so, so much for everything. And last but not least, I want to thank my students for keeping me thinking about the challenges they face when they transition to college. I hope that I am doing not too shabby a job in trying to help them along on their ways. 


\section{COLLEGE WOMEN IN}

THE NUCLEAR AGE 
